\title{
Feline immunodeficiency virus infection: a comparative study of different diagnostic techniques
}

[Infecção pelo virus da imunodeficiência felina: estudo comparativo de diferentes técnicas de diagnóstico]

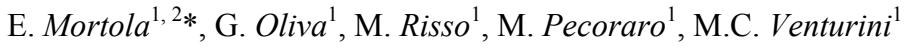 \\ ${ }^{1}$ Facultad de Ciencias Veterinarias, Universidad Nacional de La Plata, Argentina \\ ${ }^{2}$ London School of Hygiene and Tropical Medicine \\ Department of Infectious and Tropical Diseases - ROOM 221 \\ Keppel Street \\ London WC1E 7HT, UK
}

\begin{abstract}
This study evaluated an indirect immunofluorescence assay (IFA) to detect feline immunodeficiency virus infection (FIV) antibody in a comprehensive epidemiological survey of FIV in Argentina. IFA modified in our laboratory, was compared with two other immunoassays, western blot (WB) and a sandwich immunochromatographic commercial kit (SI), and also with a direct polymerase chain reaction (PCR) method that detects proviral DNA. IFA showed to be a test with high sensitivity and specificity, and could be useful as a diagnostic tool in epidemiological studies. The presence of a low percentage of results with non-specific reactivity in the IFA could be resolved with further testing or use of an alternative method.
\end{abstract}

Keywords: feline immunodeficiency virus, immunofluorescence assay, western blot, polymerase chain reaction

\section{RESUMO}

Avaliou-se a técnica de imunofluorescência indireta (IFA) na deteç̧ão de anticorpos contra o vírus da imunodeficiência felina (FIV) numa pesquisa epidemiológica do FIV na Argentina. A IFA foi modificada e comparada com duas outras técnicas imunológicas: western blot (WB) e imunocromatografia em camadas (SI) com kit comercial e também com reação em cadeia de polimerase (PCR) para detecção do DNA proviral. A IFA mostrou ser um teste com alta sensibilidade e especificidade e poderá ser empregada como ferramenta útil em estudos epidemiológicos. A baixa porcentagem de reatividade não especifica pode ser esclarecida com testes mais avançados ou usando métodos alternativos.

Palavras-chave: vírus da imunodeficiência felina, imunofluorescência indireta, western blot, reação em cadeia de polimerase

Recebido para publicação em 2 de dezembro de 2002

Recebido para publicação, após modificações, em 23 de julho de 2003

E-mail: eduardo.mortola@1shtm.ac.uk

*Corresponding address 


\section{INTRODUCTION}

Since the first isolation of feline immunodeficiency virus (FIV) by Pedersen (1987) in the United States and the availability of diagnostic tests, FIV has been identified in many other countries including the United Kingdom (Harbour et al., 1988), Japan (Ishida et al., 1988), Australia (Sabine et al., 1988) and New Zealand (Swinney et al., 1989). FIV has been classified as a new member of the subfamily Lentivirinae in the family Retroviridae (Pedersen et al., 1987), which includes human and simian immunodeficiency viruses. FIV infection results in progressive impairment of the immune system, even in clinically normal animals, and involves loss of CD4+ lymphocytes, dysregulation of cytokine production, and altered lymphocyte function (Burkhrad, Hoover, 1998).

During the last quarter century, the demand for high quality preventive and critical veterinary care of domestic cats has grown. Diagnosis of many feline diseases has become increasingly dependent on the combination of clinical findings and the laboratory diagnostic testing. However, the use and interpretation of many of these tests has been controversial.

The definitive diagnostic test for FIV is the isolation of the virus from blood lymphocytes, but this test is too cumbersome and expensive for routine use. Fortunately, most FIV-infected cats develop antiviral antibodies that can be detected in serum within six to eight weeks of infection, and a high correlation exists between the results of serology and virus isolation (Yamamoto et al., 1988; Ishida et al., 1989).

The immunofluorescence assay (IFA) has been widely used for clinical laboratory diagnosis of a range of infectious diseases, including human immunodeficiency virus (HIV), and has been reported to be nearly or equally as sensitive as western blot (WB) analysis for the detection of AIDS-associated retrovirus antibodies (Carlson et al., 1987; Kaminsky et al., 1985). WB is a powerful technique that complements the arsenal of serologic methods used in virology. It can be used for the characterization of either component in the immune complex: the antigen or the antibody (Egberink et al., 1991).
Detection of proviral DNA of FIV in tissues, such as spleen, bone marrow and cervical lymph node by polymerase chain reaction (PCR) has been reported and shown to have high test reproducibility (Klein et al., 1999; Leutenegger et al., 1999).

In Argentina, FIV isolation and detection of FIVspecific antibodies has been reported (Pecoraro et al., 1996; Tohya et al., 1994). However, the prevalence of FIV is unknown. Seroepidemiological surveys are in progress, but the high cost of commercially available kits restricts their widespread use in the general cat population. The purpose of this study was to evaluate four methods of FIV antibody detection, with the aim of identifying a cost-effective and accurate sero-diagnostic test, in a comprehensive epidemiological survey of FIV in Argentina.

\section{MATERIALS AND METHODS}

Serum samples for serologic tests and peripheral blood mononuclear cells (PBMC) for PCR analysis were taken from 120 domestic cats from The Central Veterinary Small Animal Hospital of La Plata University, and from private veterinarians. Samples were obtained from cats of different breeds, ages and both sexes, with and without clinical signs compatible with FIV infection. Positive and negative control sera, from confirmed infected and disease-free cats respectively, were used in the experiments (Kindly provided by Dr. Y. Tohya from the Department of Veterinary Microbiology, University of Tokyo, Japan).

A "Duo Speed" commercial kit ${ }^{1}$ based on the sandwich immunochromatographic (SI) principle was used. The test was performed according to the manufacturer's protocols.

The IFA test was modified in the laboratory, and compared with WB and commercially available immunoassay kit assay (SI), for the detection of virus-specific antibodies, and with a direct (PCRbased) method that detects the proviral DNA. The IFA test was performed on twelve-well

${ }^{1}$ Bio Veto Laboratory Test-Diagnostic Veterinaire, France 
microscope slides using crandell feline kidney (CRFK) cells infected with FIV-Petaluma strain (kindly provided by Dr. N.C. Pedersen, University of California-Davis) and non-infected CRFK cells suspended in $1: 5$ to $1: 10$ ratio respectively. The cells were fixed using two different procedures. In the first, the cell suspension was incubated overnight in a humidified incubator at $37^{\circ} \mathrm{C}$ in $5 \%$ of $\mathrm{CO}_{2}$ in air, and then rapidly washed in phosphate buffer saline solution (PBS), and fixed in cold $\left(-20^{\circ} \mathrm{C}\right)$ acetone for $30 \mathrm{~min}$. In the second, the slide carrying the cells was air dried at room temperature, and fixed in acetone as in the first procedure. The slides were stored in an air-tight, water-free container at $-20^{\circ} \mathrm{C}$ until use.

The assay was performed by adding 151 per well of sample sera or control sera diluted 1:10 and $1: 20$ in PBS, and incubated at $37^{\circ} \mathrm{C}$ in $5 \%$ of $\mathrm{CO}_{2}$ in air for $45 \mathrm{~min}$ in a moist chamber. The slides were then washed three times for $5 \mathrm{~min}$ each with PBS and then air-dried. Goat anti-cat IgG FITC conjugate ${ }^{2}$, diluted 1:1000 in PBS, was added to each well in a volume of $15 \mu$ l and incubated as above. After washing three times with PBS, the air-dried slides were mounted under 50\% glycerol in PBS and were read by two independent observers using an UV light microscope ${ }^{3}$ in a double-blind study.

The immunoblot assay was performed using the technique as described by Miyazawa at al. (1989). The viral proteins were separated by electrophoresis on $12 \%$ polyacrylamide gels and then transferred to a nitrocellulose membrane. The blotted membrane was sliced and incubated with appropriately diluted serum samples at $37^{\circ} \mathrm{C}$ for $2 \mathrm{~h}$, then washed three times with PBS and incubated once more with goat anti-cat IgG peroxidase conjugate ${ }^{4}$ at $37^{\circ} \mathrm{C}$ for $1 \mathrm{~h}$. The reaction was visualized by addition of a diaminobenzidine-hydrogen peroxide substrate.

A double PCR procedure was developed for the detection of proviral FIV DNA. Primers were designed according to sequence data published by Rimstad and Ueland (1992). DNA was isolated from PBMC cells with a genomic DNA

${ }^{2}$ Sigma BioSciences, USA

${ }^{3}$ Olympus BH2-RFL

${ }^{4}$ Jackson ImmunoResearch Laboratories, Inc. Baltimore, USA purification $\mathrm{kit}^{5}$ according to the manufacturer's instructions. A 203 bp fragment of the gag gene was amplified (5'-ATATGACGGTGTCTACT GCTGCTGAAGGCAAGAGAAGGACTAGGA GTAGGGTAATGGTCTGGGAGCATCTCTAC ACTGCATCCTAGCTGGTGCTAGGAGGTGA GGAGGTCCAACCTGGTGATCCTACAATCC GTTATTCTTGGCAGGCGGATACAGATGAC ACTGAGTATGATCGTACCCTCTAAAGTAC TTTCTGGTTTAAG-3') (Oliva et al., 2000) The reaction was carried out in two-steps. First, $50 \mu \mathrm{l}$ of the mixture reaction consisting in $4 \mu 110 \mathrm{mM}$ deoxynucleotide mix (dNTP), $0.5 \mu \mathrm{l} 2 \mathrm{U}$ Taq polymerase $^{6}, 0.5 \mu 120 \mathrm{pmol}$ of each primer, $10 \mu \mathrm{l}$ DNA sample, $0.01 \%$ gelatin $(\mathrm{w} / \mathrm{v}), 5 \mu \mathrm{l} 10$-fold concentrated reaction buffer ${ }^{7}, 3.5 \mathrm{mM} \mathrm{MgCl}_{2}$ and distilled water up to $50 \mu \mathrm{l}$, was overlaid with paraffin oil and cycled in a DNA Thermal cycler $480^{8}$ for 25 cycles with $45 \mathrm{~s}$ at $94^{\circ} \mathrm{C}, 1 \mathrm{~min}$ at $55^{\circ} \mathrm{C}$ and $2 \mathrm{~min}$ at $72^{\circ} \mathrm{C}$. In the second step $5 \mu \mathrm{l}$ of the first PCR amplification product was used in the same manner with the exception of gelatin and $1.5 \mathrm{mM}$ of $\mathrm{MgCl}_{2}$. The mixture was subjected to 30 cycles of $1 \mathrm{~min}$ at $94^{\circ} \mathrm{C}, 1 \mathrm{~min}$ at $55^{\circ} \mathrm{C}$ and $1 \mathrm{~min}$ at $72^{\circ} \mathrm{C}$. Amplified PCR products were visualized by electrophoresis on 2\% agarose gels in tris-borato-edta buffer (TBE) stained with ethidium bromide.

The agreement between tests was evaluated by calculating Cohen's Kappa coefficient. A value of 1 indicates perfect agreement, while a value of 0 indicates that agreement is no better than chance. In general, a value between 0.4 and 0.5 is considered to represent moderate agreement. This method was designed to measure the agreement between different tests in the absence of a gold standard (Fleiss, 1981; Norman, Streiner, 1996). Statistical analysis was carried on using Fisher's exact test.

\section{RESULTS}

The results are summarised in Table 1, where the four tests used are compared and the data statistically analysed.

\footnotetext{
${ }^{5}$ Wizard genomic kit, Promega-Madison, USA

${ }^{6}$ Promega-Madison, USA

${ }^{7}$ SuperMix, Gibco BRL Madison, USA

${ }^{8}$ Perkin-Elmer Corp, USA
} 
Table 1. Comparison of immunofluorescence assay (IFA), western blot (WB) and sandwich immunochromatographic (SI) for antobodies, and polymerase chain reaction (PCR) for genome in the diagnosis of feline immunodeficiency virus

\begin{tabular}{|c|c|c|c|c|c|c|c|c|c|}
\hline & \multicolumn{3}{|c|}{ WB } & \multirow[b]{2}{*}{$\begin{array}{l}\mathrm{Se} \\
\%\end{array}$} & \multirow[b]{2}{*}{$\begin{array}{c}\text { Sp } \\
\%\end{array}$} & \multirow[b]{2}{*}{$\begin{array}{l}\mathrm{C} \\
\%\end{array}$} & \multirow[b]{2}{*}{$\begin{array}{l}\mathrm{D} \\
\%\end{array}$} & \multirow[b]{2}{*}{$\mathrm{P}$-value } & \multirow[b]{2}{*}{ K } \\
\hline & Positive & Negative & Total & & & & & & \\
\hline \multicolumn{10}{|l|}{ IFA } \\
\hline Positive & 33 & 13 & 46 & 97.1 & & & & & \\
\hline Negative & 1 & 73 & 74 & & 84.9 & & & & \\
\hline \multirow[t]{3}{*}{ Total } & 34 & 86 & 120 & & & 87.3 & 11.7 & $<0.0001$ & 0.740 \\
\hline & \multicolumn{3}{|c|}{ SI } & & & & & \multirow[b]{2}{*}{ P-value } & \\
\hline & Positive & Negative & Total & $\begin{array}{l}\mathrm{Se} \\
\%\end{array}$ & $\begin{array}{l}\text { Sp } \\
\%\end{array}$ & $\begin{array}{l}\mathrm{C} \\
\%\end{array}$ & $\begin{array}{l}\mathrm{D} \\
\%\end{array}$ & & \\
\hline \multicolumn{10}{|l|}{ IFA } \\
\hline Positive & 56 & 4 & 60 & 96.8 & \multirow{3}{*}{93.9} & & & & \\
\hline Negative & 2 & 58 & 60 & & & & & & \\
\hline \multirow[t]{3}{*}{ Total } & 58 & 62 & 120 & & & 95 & 5 & $<0.0001$ & 0.906 \\
\hline & \multicolumn{3}{|c|}{ PCR } & & & & & \multirow[b]{2}{*}{$\mathrm{P}$-value } & \multirow[b]{2}{*}{$\mathrm{K}$} \\
\hline & Positive & Negative & Total & $\begin{array}{l}\mathrm{Se} \\
\%\end{array}$ & $\begin{array}{l}\text { Sp } \\
\%\end{array}$ & $\begin{array}{l}\mathrm{C} \\
\%\end{array}$ & $\begin{array}{l}\mathrm{D} \\
\%\end{array}$ & & \\
\hline \multicolumn{10}{|l|}{$\overline{\mathrm{IFA}}$} \\
\hline Positive & 43 & 27 & 70 & 100.0 & & & & & \\
\hline Negative & - & 50 & 50 & & 65.0 & & & & \\
\hline Total & 43 & 77 & 120 & & & 77.5 & 22.5 & $<0.0002$ & 0.569 \\
\hline
\end{tabular}

$\mathrm{Se}=$ Sensitivity; $\mathrm{Sp}=$ Specificity $; \mathrm{C}=$ Concordance rate $\mathrm{D}=$ Discrepancy rate

$\mathrm{P}$-value $=$ Fisher's exact test (significant values $P<0.05$ ); $=$ Kappa coefficient.

\section{DISCUSSION}

As the diagnosis of immunodeficiency diseases like FIV the risk of leaving an FIV-infected cat into an otherwise clean colony, it is necessary that the diagnostic test used has a high sensitivity. The positive results should be confirmed using a more specific test, when it is important to accurately rule out the presence of an infection or when the course of treatment will be markedly altered in view of a positive result.

All the commonly used diagnostic tests for FIV detect virus-specific antibodies rather than the virus itself. Most cats seroconvert within six to eight weeks of infection, however, a few cats develop a very low antibody response or no response at all, even after several months of infection. These responses are impossible to detect by immunoserologic tests and therefore give false negative results. In this case, the way to detect the disease is by virus isolation from PBMC (Yamamoto et al., 1988). However, very recently a commercial test to detect the virus itself has become available?

${ }^{9}$ Vita-Tech FIV DNA test, Canada
False positive results may occur in young kittens, offspring of a FIV infected seropositive queen because of maternal antibody transfer through the placenta or colostrums. Although, FIV does not appear to be transmitted readily from queens to kittens through the placenta, the possibility of infection during delivery exists (Yamamoto et al., 1989). In these cases, the checking of the kittens with a second test two months later could be useful to confirm or discard FIV infection.

During the development of IFA, nonspecific reactions in both positive and negative sera were found in approximately $6 \%$ of the samples tested. Several papers (Barr et al., 1991; Reid et al., 1992) reported up to $10 \%$ of these kinds of reactions using feline sera could cause false positive results in the absence of either correct control sera or careful examination. For a better understanding, nonspecific reactions were categorized into four groups according to their appearance: presence of a dull, flat, grainy, green fluorescence in the whole cell, bright patchy fluorescence in the cytoplasm of the cell, perinuclear fluorescence resembling a ring just around the cell nucleus, and presence of fluorescence staining only in the cell nucleus. 
The first two patterns could correspond to damaged cells and other debris, while the third and fourth are rare and usually attributed to the presence of antinuclear antibodies. In this subset of cases, we suggest a higher dilution $(1: 20 \sim 1: 50)$ to sufficiently dilute out the nonspecific reacting elements of the serum, plus a careful evaluation of IFA in comparison with a negative control. When, as a result of dilution, it is not possible to reach conclusive data, it is recommended an instant new sample if the sera had not been properly preserved, or in the case of a highly nonspecific reaction, a follow-up sample taken two to four weeks later. As has been found in studies with HIV IFA (Carlson et al., 1987; Gallo et al., 1986) a high nonspecificity titre could cover up the presence of a low titre level of specific antibodies. It is important to note that an uncorrected interpretation of the assay due to operator error may turn the IFA a less specific test.

IFA and SI tests yielded a very similar sensitivity and specificity, and the agreement between these two tests was very good (Kappa coefficient $=0.906$ ). The IFA had a lower specificity when it was compared to WB, because the anti-FIV p24 specific core protein antibody was detected in our immunoblot procedure. WB is considered to be a more specific test for antibody detection (Jarrett et al., 1991). The agreement between the IFA and the WB tests was good (Kappa coefficient $=0.740$ )

When IFA versus PCR were compared, the specificity of IFA was found to be quite low and the agreement between these tests was only fair (Kappa coefficient $=0.569$ ). The detection of specific nucleic acids by the double PCR was a method used to identify proviral FIV DNA, which highly increased the specificity. The fact that the PCR did not detect proviral FIV DNA in all samples from seropositive cats, indicated that the rate of infected PBMC in the cats might be very low, as has it been documented in HIV infection (Simmonds et al., 1990). Alternatively, the primers used in these experiments may not necessarily detect all the FIV types and subtypes, due to the relatively high intrinsic mutation rates of gag, pol and env genes in lentivirus (Greene et al., 1993). A phylogenetic analysis based on the nucleotide sequences of LTR (long terminal repeat) regions of the genome of the virus, demonstrated the existence of four groups
(Sodora et al., 1994; Kakinuma et al., 1995; Yamada et al., 1995) including the Argentinean subtype which is quite distant from other reported isolates and forms a new FIV group (Pecoraro et al., 1996). However, for the majority of the groups little sequence data are available (Uema et al., 1999).

The commercial availability and convenience of the SI makes it a more useful test than IFA especially for small diagnostic laboratories with routinely fewer samples. However, the high cost of the kit in comparison to IFA restricts a widespread use to study the prevalence of FIV in a large cat population.

As a result of an attentive analysis of the Table 1 it is suggested that IFA could be easily used instead of SI. The low cost of IFA makes it a more economical test with high sensitivity/specificity, and a low rate of discrepancy with the other immunological techniques mentioned above. WB could be used when results need to be confirmed by other specific tests. A startling finding of this study was the high discrepancy rate between IFA and PCR, therefore we recommend that the use of PCR should be restricted to occasions when virus genome data is necessary for research purposes.

The available tests for detection of FIV antibodies in general perform well and are useful as diagnostic tools. Although obvious, it is useful to emphasize the fact that no test is always $100 \%$ accurate under all conditions and therefore critical decisions about patient care should not only be based on a single test's results, but should also be assessed considering the patient history and clinical signs for FIV.

\section{REFERENCES}

BARR, M.C.; POUGT, M.B.; JACOBSON, M.S. et al. Comparison and interpretation of diagnostic tests for feline immunodeficiency virus infection. J. Am. Vet. Med. Assoc., v.199, p.1377-1381, 1991.

BURKHARD, M.J.; HOOVER, E.A. Feline immunodeficiency virus (FIV): immnunopathogenesis. Feline Pract., v.26, p.10-13, 1998.

CARLSON, J.R.; YEE, J.; HINRICHS, S.H. et al. Comparison of indirect immunofluorescence and Western blot for detection of anti-human immunodeficiency virus antibodies. J. Clin. Microbiol., v.25, p.494-497,1987. 
EGBERINK, H.F.; LUTZ, H.; HORZINEK, M.C. Use of western blot and radioimmunoprecipitation for diagnostic of feline leukemia and feline immunodeficiency virus infections. J. Am. Vet. Med. Assoc., v.199, p.1362-1364, 1991.

FLEISS, J.L. Statistical methods for rates and proportions. 2.ed. New York: Wiley \& Sons. 1981.

GALLO, D.; DIGGS, J.L.; SHELL, G.R. at al. Comparison of detection of antibody to adquired immune deficiency syndrome virus by enzyme immunoassay, immunofluorescence and western blot methods. J. Clin. Microbiol., v.23, p.1049-1051, 1986.

GREENE, W.K.; MEERS, J.; DEL FIERRO, G. et al. Extensive sequence variation of feline immnunodeficiency virus env genes in isolates from naturally infected cats. Arch. Virol., v.133, p.51$62,1993$.

HARBOUR, D.A; WILLIAMS, P.D.; GRUFFYDD-JONES, T.J. et al. Isolation of a T-lymphotropic lentivirus from a persistently leucopenic domestic cat. Vet. Rec., v.122, p.84-86, 1988.

HOHDATSU, T.; YAMADA, M.; OKADA, M. et al. Detection of feline immunodeficiency proviral DNA in peripheral blood lymphocytes by the polymerase chain reaction. Vet. Microbiol., v. 30, p.113-123, 1992

ISHIDA, T.; WASHIZU, T.; TORIYABE, K. et al. Detection of feline T - lymphotropic lentivirus (FTLV) infection in Japanese domestic cats. Jpn. J. Vet. Sci., v.50, p.39-44, 1988.

ISHIDA, T.; WASHIZU, T.; TORIYABE, K. et al. Feline immunodeficiency virus infection in cats of Japan. J. Am. Vet. Med. Assoc., v.194, p.221-225, 1989.

JARRETT, O.; PACITTI, A.M.; HOSIE, M.J. et al. Comparison of diagnostic methods for feline leukemia virus and feline immunodeficiency virus. J. Am. Vet. Med. Assoc., v.199, p.13621364,1991

KAKINUMA, S.; MOTOKAWA, K.; HOHDATSU, T. et al. Nucleotide sequence of feline immunodeficiency virus: classification of Japanese isolates into two subtypes which are distinct from non-Japanese subtypes. J. Virol., v.69, p.3639-3646, 1995.

KAMINSKY, L.S.; MCHUGH, T.; STITES, D. et al. High prevalence of antibodies to acquired immune deficiency syndrome (AIDS)-associated retrovirus (ARV) in AIDS and related conditions but not in other disease states. Proc. Natl. Acad. Sci., v.82, p.5535-5539, 1985.

KLEIN, D.; JANDA, P.; STEINBORN, R. et al. Proviral load determination of different feline immunodeficiency virus isolates using real-time polymerase chain reaction: influence of mismatches on quantification. Electrophoresis, v.20, p.291-299, 1999.

LEUTENEGGER, C.M.; KLEIN, D.; HOFMANN-LEHMANN, $\mathrm{R}$. et al. Rapid feline immunodeficiency virus provirus quantitation by polymerase chain reaction using the Taq Man fluorogenic real-time detection system. J. Virol. Methods, v.78, p.105-116, 1999.

MIYAZAWA, T.; FURUYA, T.; ITAGAKI, S. et al. Preliminary comparisons of the biological properties of two strains of feline immunodeficiency virus (FIV) isolated in Japan with FIV Petaluma strain isolated in the United States. Arch. Virol., v.108, p.59-68, 1989.
NORMAN, G.R.; STREINER, D.L. Bioestadística. Madrid: Mosby \& Doyma Libros SA,1996.

OLIVA, G.A.; VILA ROZA, M.V.; GALOSI, C.M. et al. Infección con el virus de la inmunodeficiencia felina: Desarrollo y aplicación de una técnica de doble reacción de la polimerasa (PCR) para el diagnóstico. Analecta Vet., v.20, p.11-15, 2000.

PECORARO, M.R.; TOMONAGA, K.; MIYAZAWA, T. et al. Genetic diversity of Argentina isolates of feline immunodeficiency virus. J. Gen. Virol., v.77, p.2031-2035, 1996.

PEDERSEN, N.C.; HO, E.W.; BROWN, M.L. et al. Isolation of a T-lymphotropic virus from domestic cats with an immunodeficiency-like syndrome. Science, v.235, p.790-793, 1987.

REID, R.W.; BARR, M.C.; SCOTT, F.W. Retrospective serologic survey for the presence of feline immunodeficiency virus antibody: a comparison of ELISA and IFA techniques. Cornell Vet., v.82, p.359-369, 1992.

RIMSTAD, E.; UELAND, K. Detection of feline immunodeficiency virus by a nested polymerase chain reaction. $J$. Virol. Methods, v.36, p.239-248, 1992.

SABINE, M.; MICHELSEN, J.; THOMAS, F. et al. Feline AIDS. Aust. Vec. Pract., v.18, p.105-107, 1988.

SIMMONDS, P.; BALFE, P.; LUDLAM, C.A. et al. Analysis of sequence diversity in hypervariable regions of the external glycoprotein of human immunodeficiency virus type1. J. Virol., v.64, p.5840-5850, 1990.

SODORA, D.L.; SHPAER, E.G.; KICHELL, B.E. et al Identification of three feline immunodeficiency virus (FIV) env gene subtypes and comparison of the FIV and human immunodeficiency virus type 1 evolutionary patterns. J. Virol., v.68, p.2230-2238, 1994.

SWINNEY, G.R.; PAULI, J.V.; JONES, B.R. et al. Feline Tlymphotropic Virus (FTLV)(feline immunodeficiency virus infection) in cats in New Zealand. New Zeal. Vet. J., v.37, p.4143,1989

TOHYA, Y.; CASTELLANO, M.C.; NORIMINE, J. et al. Anticuerpos contra el virus de la inmunodeficiencia felina: Primera comprobación en Argentina. Rev. Med. Vet., v.75, p.242246, 1994.

UEMA, M.; IKEDA, Y.; MIYAZAWA, T. et al. Feline immunodeficiency virus subtype $\mathrm{C}$ is prevalent in Northern part of Taiwan. J. Vet. Med. Sci., v.61, p.197-199, 1999.

YAMADA, H.; MIYAZAWA, T.; TOMONAGA, K. et al. Phylogenetic analysis of the long terminal repeat of feline immunodeficiency viruses from Japan, Argentina and Australia. Arch. Virol., v.140, p.41-52, 1995.

YAMAMOTO, J.K.; HANSEN, H.; HO, E.W. et al. Epidemiological and clinical aspects of feline immunodeficiency virus infection in cats from the Continental United States and Canada and possible mode of transmission. J. Am. Vet. Med. Assoc., v.194, p.213-220, 1989.

YAMAMOTO, J.K.; SPARGER, E.; HO, E.W. et al. Pathogenesis of experimentally induced immunodeficiency virus infection in cats. Am. J. Vet. Res., v.4, p.1246-1258, 1988. 